\title{
Chemical parameters and ruminal disappearance of Secale cereale rye forage in different harvest systems with or without fungicide
}

\section{Parâmetros bromatológicos e desaparecimento ruminal da forragem do centeio Secale cereale em diferentes sistemas de corte com ou sem fungicida}

\author{
Julio Cezar Heker Junior ${ }^{1 *}$; Mikael Neumann²; Marcelo Cruz Mendes ${ }^{2}$; André \\ Martins de Souza ${ }^{3}$; Leslei Caroline Santos ${ }^{4}$; Emylli Pereira e Silva ${ }^{5}$; Giovanna \\ Bobato Pontarolo ${ }^{6}$; Rômulo Silva de Oliveira ${ }^{7}$; Rafaela Guimarães Pinto ${ }^{8}$
}

\section{Highlights:}

The use of one cut at the vegetative stage improved the composition of fiber carbohydrates, which resulted in better dry matter disappearance rates at the rumen level.

Two cuts at the vegetative stage produced two harvests of excellent nutritional quality and ruminal disappearance. The application of fungicide led to significant improvements in the contents of crude protein and mineral matter and a higher dry matter disappearance in the rumen.

\begin{abstract}
The objective of the study was to evaluate the chemical parameters and the ruminal disappearance of dry matter of forage from the rye Secale cereale, cv. Temprano managed in different harvest regimes at the vegetative stage, with or without application of a fungicide based on Fluxapyroxade + Piraclostrobin at the pre-flowering stage. This was a randomized block experimental design and the treatments consisted of evaluating the forage harvested at floury grain stage, as follow, SCSF: no cut at the vegetative stage, no application of fungicide; SCCF: no cut at the vegetative stage with fungicide application; UCSF: one cut at the vegetative stage, no application of fungicide; UCCF: one cut with fungicide application; DCSF: two cuts at the vegetative stage, no fungicide application; DCCF: two cuts with fungicide application. In general, one cut at the vegetative stage and a subsequent cut for ensiling at floury grain stage was the best system used in cv. Temprano, based on the chemical parameters and ruminal disappearance. This
\end{abstract}

1 Prof. Dr., Departamento de Medicina Veterinária, Universidade Estadual do Centro-Oeste, UNICENTRO, Guarapuava, PR, Brasil. E-mail: jr_heker@hotmail.com

2 Profs. Drs., Curso de Pós-Graduação em Agronomia na área de Produção Vegetal, UNICENTRO, Centro de Ciências Agrárias e Ambientais, Guarapuava, PR, Brasil.E-mail: neumann.mikael@hotmail.com; mcruzm@gmail.com

3 Discente do Curso de Doutorado do Programa de Pós-Graduação em Ciência Animal, Universidade Estadual de Londrina, UEL, Londrina, PR, Brasil. E-mail: andrems 92@hotmail.com

4 Discente do Curso de Doutorado do Programa de Pós-Graduação em Zootecnia, Universidade Estadual de Oeste do Paraná, UNIOESTE, Marechal Cândido Rondon, PR, Brasil. E-mail: lesleicaroline@hotmail.com

5 Discente do Curso de Mestrado do Curso de Pós-Graduação em Agronomia na área de Produção Vegetal, UNICENTRO, Guarapuava, PR, Brasil. E-mail: emylli.pe95@gmail.com

6 Discente do Curso de Mestrado do Programa de Pós-Graduação em Ciências Veterinárias, UNICENTRO, Guarapuava, PR, Brasil. E-mail: giovannabpontarolo@hotmail.com

7 Discente do Curso de Graduação em Medicina Veterinária, UNICENTRO, Guarapuava, PR, Brasil. E-mail: romulo_ivp99@ hotmail.com

8 Discente do Curso de Mestrado do Programa de Pós-Graduação em Zootecnia, Universidade Estadual Paulista Júlio de Mesquita Filho, Câmpus de Ilha Solteira, UNESP, Ilha Solteira, SP, Brasil. E-mail: guimafara@hotmail.com

Author for correspondence

Received: Aug. 01, 2019 - Approved: May 18, 2020 
system provided a better composition of fiber carbohydrates with lower contents of Acid Detergent Fiber $(41.55 \%)$ and Lignin $(10.79 \%)$ after cutting and resulted in a better disappearance rate of dry matter at the rumen level $(0.46 \%)$ per hour of exposure, highlighting the cut at the vegetative stage that produced a material with $20.76 \%$ Crude Protein and $52.69 \%$ Neutral Detergent showing its nutritional quality for use in grazing land or as haylage. The application of fungicide provided significant improvements in the contents of crude protein $(8.24 \%$ vs $7.23 \%)$ and mineral matter $(3.02 \%$ vs $2.82 \%)$ of the plant at the time of ensiling, which generated better dry matter disappearance rates in the rumen.

Key words: Crude protein. Fiber carbohydrates. Pyraclostrobin. Secale cereale.

\section{Resumo}

O objetivo do estudo foi avaliar os parâmetros bromatológicos e o desaparecimento ruminal da matéria seca da foragem de centeio Secale cereale, cv. Temprano manejado em diferentes regimes de cortes no estádio vegetativo, com ou sem aplicação de fungicida a base de Fluxapiroxade + Piraclostrobina no estádio de pré-florescimento. O delineamento experimental foi o de blocos ao acaso e os tratamentos constaram da avaliação das forragens colhidas no estádio de grão farináceo, sendo SCSF: sem corte no vegetativo e sem aplicação de fungicida; SCCF: sem corte no vegetativo com aplicação de fungicida; UCSF: um corte no vegetativo sem aplicação de fungicida; UCCF: um corte com aplicação de fungicida; DCSF: dois cortes no vegetativo sem aplicação de fungicida; DCCF: dois cortes com aplicação de fungicida. De maneira geral, a realização de um corte no estádio vegetativo e posterior corte para ensilagem no estádio de grão farináceo foi o melhor sistema empregado no centeio cv. Temprano com base nos parâmetros de bromatologia e desaparecimento ruminal. Esse sistema proporcionou melhor composição dos carboidratos fibrosos com menores teores de Fibra em Detergente Ácido (41,55\%) e Lignina $(10,79 \%)$ após o corte e gerou melhor taxa de desaparecimento ruminal da matéria seca a nível ruminal $(0,46 \%)$ por hora de exposição, ressaltando ainda o corte do vegetativo que produziu um material com $20,76 \%$ de Proteína Bruta, Fibra em detergente neutro de 52,69\% evidenciando a sua qualidade nutricional para uso em pastejo ou como silagem pré-secada. O uso do fungicida proporcionou melhoras significativas nos teores de proteína bruta $(8,24 \%$ vs $7,23 \%)$ e matéria mineral $(3,02 \%$ vs $2,82 \%)$ da planta no momento da ensilagem, o que gerou melhores índices de desaparecimento da matéria seca no rúmen.

Palavras-chave: Carboidratos fibrosos. Piraclostrobina. Proteína bruta. Secale cereale.

\section{Introduction}

Animal production is more economically viable when it is possible to intensively exploit pastures. However, in some periods of the year, due to climatic variations such as drought and periods with low temperatures, the maintenance of animal production levels is impaired by the use of pastures, due to the decrease in the amount and quality of available forages (Coan, Freitas, Reis, \& Rodrigues, 2001).

According to Phillips, Rao, Dalrymple and Klepper (1996), the cultivation of winter cereals, such as oats (Avena spp.), wheat (Triticum sativum L.) and rye (Secale cereale L.), occupy approximately $35 \%$ cultivated areas used by world agriculture. The same authors also emphasize that the use of these species is an alternative for earlier production in periods of shortage and taking into account nutritional quality and production potential, there is the ability to improve the use of resources such as land, infrastructure and labor. In this context, the use for the production of preserved forages, such as hay, haylage and silage, has become a usual practice, to prevent risks of food shortage in cases of bad weather and/or greater standardization of the animals' diet during the year (Lehmen, Fontaneli, Fontaneli, \& Santos, 2014).

Rye is an annual winter grass, with a clumping growing habit, with an average height of $1.2 \mathrm{~m}$ to $1.8 \mathrm{~m}$, has a wide adaptation of crops, and can be 
found from sea level up to 4,300 $\mathrm{m}$ in altitude, has good tolerance to soils with low fertility and, in comparison to other winter forages, produce more in months with greater intensity of cold (Fontaneli et al., 2016).

The final production of winter grasses, mainly grains, will assist in the fermentation process and is directly related to leaf diseases, because excess rain, accumulation of cloudy days, higher temperatures at the end of the cycle, are favorable to the occurrence and the increase in the severity of diseases, which is among the main difficulties faced by producers in southern Brazil (Reis \& Casa, 2007).

According to Pepler, Gooding, Ford and Ellis (2005), the use of fungicides for greater control of diseases has contributed to greater production due to the ability to maintain a larger photosynthetic area in the canopy, mainly at the end of the cycle, which results in higher grain filling. There are still reports of the ability of some active ingredients to alter the physiology of the treated plants and consequently their chemical composition (Grossmann \& Retzlaff, 1997).

Given the above, the objective of the study was to evaluate the nutritional quality of forage and the ruminal disappearance of dry matter of rye cv. Temprano, managed under different harvest regimes at the vegetative stage, with or without application of a fungicide based on Fluxapyroxade + Piraclostrobin at the pre-flowering stage.

\section{Material and Methods}

The experiment was conducted at the Animal Production Center (NUPRAN), located in the municipality of Guarapuava, State of Paraná, in the subtropical zone (Maack, 2002), at the geographical coordinates $25^{\circ} 23^{\prime} 02^{\prime \prime}$ South latitude and $51^{\circ} 29^{\prime} 43^{\prime \prime}$ West longitude and 1,026 $\mathrm{m}$ altitude. The climate of the region according to the Köppen classification is $\mathrm{Cfb}$ (subtropical humid mesothermal), with mild summers and moderate winter, with no defined dry season and severe frosts. The average annual rainfall is $1,944 \mathrm{~mm}$, the average annual minimum temperature is $12.7^{\circ} \mathrm{C}$, the average annual maximum temperature is $23.5^{\circ} \mathrm{C}$ and the relative humidity of the air is $77.9 \%$ (Caviglione et al., 2000).

The soil of the experimental area was classified as Latossolo Bruno Típico (Pott, Müller, \& Bertelli, 2007). Before planting, the area had the following chemical characteristics (profile from 0 to $20 \mathrm{~cm}$ ): pH CaCl 2 0,01M: 4.8; phosphorus: $1.0 \mathrm{mg} \mathrm{dm}^{-3} ; \mathrm{K}^{+}$: $0.2 \mathrm{cmol}_{\mathrm{c}} \mathrm{dm}^{-3}$; OM: $2.62 \%$; $\mathrm{Al}^{3+}: 0.0 \mathrm{cmol}_{\mathrm{c}} \mathrm{dm}^{-3}$; $\mathrm{H}^{+}+\mathrm{Al}^{3+}: 5.2 \mathrm{cmol}_{\mathrm{c}} \mathrm{dm}^{-3} ; \mathrm{Ca}^{2+}: 5.2 \mathrm{cmol}_{\mathrm{c}} \mathrm{dm}^{-3} ; \mathrm{Mg}^{2+}$ : $5.1 \mathrm{cmol}_{\mathrm{c}} \mathrm{dm}^{-3}$ and base saturation: $65.8 \%$.

The experimental material was rye (Secale cereale), cv. Temprano, and the treatments consisted of forages harvested at stage of floury grain under different cutting systems at the vegetative stage, with or without foliar application of fungicide at pre-flowering, as follow, SCSF: no cut at the vegetative stage, no application of fungicide; SCCF: no cut at the vegetative stage with fungicide application; UCSF: one cut at the vegetative stage, no application of fungicide; UCCF: one cut with fungicide application; DCSF: two cuts at the vegetative stage, no fungicide application; DCCF: two cuts with fungicide application.

The experimental field was a $540 \mathrm{~m}^{2}$ total area, divided into 36 plots of $9.45 \mathrm{~m}^{2}$ each $(3.15 \mathrm{~m} \mathrm{x} 3$ $\mathrm{m})$ corresponding to 54 linear planting areas, using an area of $4.2 \mathrm{~m}^{2}(2.1 \mathrm{~m} \mathrm{x} 2 \mathrm{~m})$ corresponding to 24 linear meters for evaluations.

No-till sowing was performed on April 12, 2017 in a uniform way for the treatments. When sowing, the row spacing was $17.5 \mathrm{~cm}$, the sowing depth was $2 \mathrm{~cm}$ with an average distribution of 220 seeds per $\mathrm{m}^{2}$.

For implementation of rye, basal fertilization was made with $280 \mathrm{~kg} \mathrm{ha}^{-1}$ fertilizer formulated 08 30-20 ( $\left.-\mathrm{N}_{2} \mathrm{O}_{5}-\mathrm{K}_{2} \mathrm{O}\right)$, respecting recommendations of the manual of fertilization and liming for the State of Paraná (Sociedade Brasileira de Ciência do Solo / Núcleo Estadual do Paraná [SBCS/NEPAR], 2017). 
Nitrogen topdressing was carried out 51 days after sowing and consisted of a single application of 444 $\mathrm{kg} \mathrm{ha}^{-1}$ urea (45-00-00), ensuring the application of $200 \mathrm{~kg} \mathrm{ha}^{-1}$ nitrogen.

Weeds were chemically controlled, firstly in desiccation before sowing, using glyphosate-based herbicide (commercial product Roundup Original ${ }^{\circledR}$ : $2.01 \mathrm{ha}^{-1}$ ); in crop management, 30 days after sowing, the herbicide based on metsulfuron-methyl (commercial product Ally ${ }^{\circledR}$ : $6.6 \mathrm{~g} \mathrm{ha}^{-1}$ ) was applied. Pest control was carried out at 30 days after sowing, according to field evaluations, using the insecticide based on Thiamethoxam + Lambda cyhalothrin (commercial product Engeo Pleno ${ }^{\circledR}: 150 \mathrm{~mL} \mathrm{ha}^{-1}$ ) and another application at 145 days after sowing, according to field evaluation.

The product based on Fluxapyroxad + Pyraclostrobin used in fungicide treatments was the commercial product Orkestra ${ }^{\mathrm{TM}} \mathrm{SC}^{\circledR}$, in the recommended dose for rye of $0.35 \mathrm{~L} \mathrm{ha}^{-1}$, at preflowering stage.

The regime of the different systems subjected to one cut or two cuts was carried out at vegetative stage, at 88 and 135 days after sowing. The lowering height followed the recommendations of Fontaneli, Santos, Nascimento Jr., Minella, \& Caierão (2009). Silages were made in equivalence of reproductive stages, with the definition of the soft dough stage, as well as the time indicated for ensiling, according to Fontaneli et al. (2009), with the cut made at 188 days, 195 days and 209 days after sowing according to zero, one and two cut systems, respectively.

Plants in the useful area of each plot $\left(4.2 \mathrm{~m}^{2}\right)$ were manually harvested with the aid of a serrated sickle. A homogeneous sample of a whole plant $(500 \mathrm{~g})$ was used to determine the dry matter content, using a forced air oven at $55^{\circ} \mathrm{C}$, to constant weight between measurements (Association of Official Analytical Chemists [AOAC], 1984).

All pre-dried samples of the original material and the forages were ground to $1 \mathrm{~mm}$ in a Wiley mill, where determinations were made for total dry matter in an oven at $105^{\circ} \mathrm{C}$ for 16 hours, crude protein (CP) by the micro Kjeldahl method, mineral matter (MM) by incineration at $550^{\circ} \mathrm{C}$ ( 4 hours) (Silva \& Queiroz, 2009). Also, samples were analyzed for neutral detergent fiber (NDF) content, according to Van Soest, Robertson, \& Lewis (1991), acid detergent fiber (ADF) and lignin (LIG), according to Goering and Van Soest (1970) and the contents of Hemicellulose (HEM) and Cellulose (CEL), estimated by the equation (HEM $=\mathrm{NDF}-\mathrm{ADF}$ and $\mathrm{CEL}=\mathrm{ADF}$ - LIG) following the methodology proposed by Silva and Queiroz (2009).

The ruminal disappearance of DM from silages was estimated by the in situ technique using nylon bags with $12 \times 8 \mathrm{~cm}$, and $50 \mu \mathrm{m}$ pores, containing approximately $5 \mathrm{~g}$ of each material, ground to $1 \mathrm{~mm}$, for later incubation in the rumen (Nocek, 1988). The incubation times used were $0,6,12,24,36$ and 48 hours. This procedure was previously submitted and approved by the Ethics Committee on Animal Experimentation of UNICENTRO, under opinion 035/2017 CEUA/UNICENTRO. For this purpose, two Jersey steers, 48 months of age, $550 \mathrm{~kg}$ average body weight, were given feed for maintenance according to National Research Council [NRC] (2001), based on corn silage and commercial concentrate with $19 \% \mathrm{CP}$ in a constant proportion of 70:30 on a dry matter basis. Animals were fistulated and cannulated, using the rumenostomy technique, previously approved by the Ethics Committee on Animal Experimentation of UNICENTRO, under letter 030/2014 - CEUA/UNICENTRO, and housed in the didactic unit of beef cattle.

The experiment was a $3 \times 2$ factorial randomized block design, with three managements of harvest (zero, one and two) and two managements of fungicide application (with and without), with six repetitions, where each repetition is represented by a plot of $9.45 \mathrm{~m}^{2}$. Data were tested by Shapiro-Wilk and Bartlett tests, to check the assumptions of normality and homogeneity of variance, respectively. Once these assumptions were met, the F-test was applied at $5 \%$ significance through analysis of variance 
(ANOVA) and then the Tukey's test was used to compare multiple means at 5\% significance. Data referring to the ruminal disappearance rate were subjected to regression analysis by the "Proc Reg" test at the level of 5\% significance in Statistical Analysis System Institute [SAS Institute] (1993).

The mathematical model used for analysis of variance was: $\mathrm{Y}_{\mathrm{ij}}=\mu+\mathrm{BL}+\mathrm{A}_{\mathrm{i}}+\mathrm{B}_{\mathrm{j}}+\mathrm{AB}_{\mathrm{ij}}+\mathrm{e}_{\mathrm{ij}}$, where: $Y_{i j}=$ harvest systems at the vegetative stage $\mathrm{i}$ in repetition $\mathrm{j} ; \mu=$ mean of treatments; $\mathrm{BL}=$ effect of the block; $A_{i}=$ effect of the harvest system $i$; $=$ no harvest or with one harvest at the vegetative stage; $B_{j}=$ effect of fungicide management $j ; j=$ with or without; $\mathrm{AB}_{\mathrm{ij}}=$ effect of the interaction between harvest system and fungicide management;

\section{Results and Discussion}

In general, there was no significant interaction between the harvest management system and foliar application of fungicide for the chemical and qualitative parameters of the forage of rye grown for silage production.

The contents of mineral matter (MM), neutral detergent fiber (NDF) and acid detergent fiber (ADF) were different $(\mathrm{P}<0.05)$ between the different harvest systems, while the $\mathrm{CP}$ values showed no significant differences, with a mean value of $7.73 \%$ at the time of ensiling regardless of the harvest system (Table 1).

The highest MM content was found in the management of two harvests $(3.27 \%)$, followed by the no harvest system, with $2.90 \%$, and the lowest value with one harvest (2.59\%). Leao et al. (2019), in the same experimental field, with the same harvest systems in different winter cereals, reported a different trend in barley where the treatment with two harvests showed a lower concentration of MM compared to the others that did not differ statistically. This difference is understood when considering the contents of the other evaluated parameters, and it can be understood that these values may be related to non-fiber carbohydrates of the plant, which makes up this stoichiometric relationship, due to the greater participation of grains in the ensiling stage.

The NDF content was higher in the system with two harvests at the vegetative stage with $76.85 \%$, the other treatments did not differ from each other (no harvest with $71.97 \%$, and one cut, with $70.13 \%$ ). The ADF content was lower in the one harvest system, with $41.55 \%$, the highest values that did not differ from each other were those with no harvest, with $46.68 \%$, and two harvests, with $47.60 \%$.

In this scenario, the use of two harvests at the vegetative stage is not desirable since it increased the fiber content and can interfere with animal intake, since the NDF has a direct relationship with the intake capacity of the ruminants and the ADF with the use of the food by these animals (Van Soest, 1994).

The cutting process tends to reduce the leaf area index and leads to the mobilization of reserves to maintain the photosynthetic rates and the development of the plant, which generates changes in its architecture, leading to changes in the cell wall components, which are linked to different biotic factors within each plant species (Taiz \& Zeiger, 2013). 
Table 1

Contents of mineral matter, crude protein, neutral and acid detergent fiber of rye cv. Temprano under different harvest systems with or without application of fungicide at pre-flowering

\begin{tabular}{|c|c|c|c|c|c|c|c|c|c|}
\hline \multirow{2}{*}{$\begin{array}{l}\text { Harvest system at } \\
\text { the vegetative stage }\end{array}$} & \multirow{2}{*}{$\begin{array}{l}\text { Fungicide } \\
\text { management }\end{array}$} & \multicolumn{2}{|c|}{ Cuts (DAE) } & \multirow{2}{*}{$\begin{array}{l}\text { Ensilable } \\
\text { forage }\end{array}$} & \multirow{2}{*}{ Mean } & \multicolumn{3}{|c|}{ Probability } & \multirow{2}{*}{$\mathrm{CV} \%$} \\
\hline & & 88 & 135 & & & $(\mathrm{~S})$ & $(\mathrm{F})$ & $(\mathrm{S} * \mathrm{~F})$ & \\
\hline & & \multicolumn{8}{|c|}{ Mineral Matter, $\%$} \\
\hline \multirow{2}{*}{ No cut } & With & - & - & 3.04 & \multirow{2}{*}{$2.90 \mathrm{~B}$} & \multirow{6}{*}{0.0001} & \multirow{6}{*}{0.0028} & \multirow{6}{*}{0.5006} & \multirow{6}{*}{6,0} \\
\hline & Without & - & - & 2.76 & & & & & \\
\hline \multirow{2}{*}{ One cut } & With & 7.24 & - & 2.69 & \multirow{2}{*}{$2.59 \mathrm{C}$} & & & & \\
\hline & Without & 7.36 & - & 2.49 & & & & & \\
\hline \multirow{2}{*}{ Two cuts } & With & 7.42 & 5.45 & 3.32 & \multirow{2}{*}{$3.27 \mathrm{~A}$} & & & & \\
\hline & Without & 7.27 & 5.39 & 3.21 & & & & & \\
\hline \multicolumn{2}{|c|}{ Mean with fungicide } & - & - & $3.02 \mathrm{a}$ & - & - & - & - & - \\
\hline \multicolumn{2}{|c|}{ Mean without fungicide } & - & - & $2.82 \mathrm{~b}$ & - & - & - & - & - \\
\hline \multicolumn{2}{|c|}{ Overall mean } & 7,32 & 5.42 & 2.92 & - & - & - & - & - \\
\hline & \multicolumn{8}{|c|}{ Crude Protein, $\%$} \\
\hline No cut & With & - & - & 8.02 & \multirow{2}{*}{$7.62 \mathrm{~A}$} & & & & \\
\hline No cul & Without & - & - & 7.22 & & & & & \\
\hline \multirow{2}{*}{ One cut } & With & 20.71 & - & 8.83 & & 0.6484 & 0.0046 & 0.2561 & \\
\hline & Without & 20.81 & - & 7.07 & $1.95 \mathrm{~A}$ & 0.0484 & 0.0040 & 0.2561 & 12,6 \\
\hline & With & 19.72 & 17.08 & 7.87 & & & & & \\
\hline IWO cuts & Without & 19.44 & 16.23 & 7.40 & $1.03 \mathrm{~A}$ & & & & \\
\hline Mean with fur & gicide & - & - & $8.24 \mathrm{a}$ & - & - & - & - & - \\
\hline Mean without $\mathrm{f}$ & Ingicide & - & - & $7.23 \mathrm{~b}$ & - & - & - & - & - \\
\hline Overall m & & 20,17 & 16.66 & 7.73 & - & - & - & - & - \\
\hline & & & & Neu & al deterge & th fiber, $\%$ & & & \\
\hline No cut & With & - & - & 73.29 & $7107 \mathrm{R}$ & & & & \\
\hline No cul & Without & - & - & 70.65 & $11.91 \mathrm{~B}$ & & & & \\
\hline One cut & With & 52.83 & - & 70.44 & $7013 \mathrm{~B}$ & 00001 & 06682 & 01027 & 49 \\
\hline One cul & Without & 52.55 & - & 69.81 & $10.15 \mathrm{D}$ & 0.0001 & 0.0002 & 0.1922 & 4,9 \\
\hline Two cuts & With & 55.27 & 59.38 & 75.70 & $7685 \mathrm{~A}$ & & & & \\
\hline wo culs & Without & 54.32 & 58.76 & 78.00 & $10.85 \mathrm{~A}$ & & & & \\
\hline Mean with fur & gicide & - & - & $73.14 \mathrm{a}$ & - & - & - & - & - \\
\hline Mean without $\mathrm{f}$ & Ingicide & - & - & $72.82 \mathrm{a}$ & - & - & - & - & - \\
\hline Overall m & & 53,74 & 59.07 & 72.98 & - & - & - & - & - \\
\hline & & & & $\mathrm{Ac}$ & detergen & fiber, $\%$ & & & \\
\hline No cut & With & - & - & 49.81 & & & & & \\
\hline No cut & Without & - & - & 43.55 & $40.68 \mathrm{~A}$ & & & & \\
\hline One cut & With & 32.59 & - & 41.24 & $41.55 \mathrm{~B}$ & 0.0001 & 0.6864 & 0.0665 & 7.8 \\
\hline One cul & Without & 32.99 & - & 41.86 & $41.55 \mathrm{~B}$ & 0.0001 & 0.0804 & 0.0005 & 1,8 \\
\hline & With & 28.04 & 38.66 & 46.69 & & & & & \\
\hline Iwo cuts & Without & 29.29 & 37.40 & 48.52 & $47.60 \mathrm{~A}$ & & & & \\
\hline
\end{tabular}


continuation

\begin{tabular}{cccccccc}
\hline Mean with fungicide & - & - & $45.12 \mathrm{a}$ & - & - & - & - \\
Mean without fungicide & - & - & $44.64 \mathrm{a}$ & - & - & - & - \\
Overall mean & 30,73 & 38.03 & 45.28 & - & - & - & - \\
\hline
\end{tabular}

Mean values followed by different capital letters, in the same column, when comparing harvest systems, are significantly different by Tukey's test at $5 \%$ significance.

Mean values followed by different lower case letters, in the same column, when comparing fungicide management, are significantly different by F-test at 5\% significance.

$\mathrm{DAE}=$ Days after emergence; S: Harvest system; F: Fungicide; S*F: Interaction between harvest system and Fungicide.

Leao et al. (2019) obtained the same behavior of the NDF values in barley, whereas in relation to the ADF, the values were significantly lower in the treatment with two harvests in wheat, triticale, black oats and barley, being higher in the treatment with one harvest.

Lehmen et al. (2014), in silage of rye cv. BRS Serrano, found values close to the present study with mean values of $6.80 \% \mathrm{CP}, 73.70 \% \mathrm{NDF}$ and $40.40 \%$ ADF. Neumann et al. (2019), in the same experimental field, investigated different winter cereals, including rye BR1 at the same phenological stage of floury grain, and observed similar CP, NDF and ADF values, with mean values of $6.88,77.78 \%$ and $40.34 \%$, respectively.

The highest $(\mathrm{P}<0.05)$ values of $\mathrm{MM}$ and $\mathrm{CP}$ were observed with the application of fungicide, $3.02 \%$ and $8.24 \%$ respectively, without application of fungicide the means were lower, $2.82 \%$ for $\mathrm{MM}$ and $7.23 \%$ for $\mathrm{CP}$.

The increase in protein content is due to the physiological activity of Pyraclostrobin, which acts in mitochondria of plant cells and inhibits the electron transport from cytochrome-b to cytochrome-c in the electron transport chain, resulting in a reduced ATP production (Anke, 1995). This decrease in ATP, according to Fagan et al. (2010), also occurs in plant cells leading to a decrease in plant maintenance respiration, promoting acidification in the cytoplasm. According to Glaab and Kaiser (1999), this acidification of the cytosol significantly increases the activity of nitrate reductase. Köehle et al. (2002) evaluated the effect of Pyraclostrobin in wheat, and proved these effects with a $10 \%$ reduction of nitrate in vitro seven days after the application, which indicates greater re-assimilation for more complex metabolites, in which nitrate is the main form plants have to absorb nitrogen.

With the use of fungicide, the contents of NDF and ADF showed no significant differences, with overall means of $72.98 \%$ for NDF and $45.28 \%$ for ADF. This is probably due to the severity of end-ofcycle diseases that reached all treatments, because the fungicide did not express the expected capacity with just one application.

The contents of hemicellulose (HEM), cellulose (CEL) and lignin (LIG) showed differences ( $P$ $<0.05$ ) between the harvest systems (Table 2). HEM was higher in the systems with one $(28.58 \%)$ and two cuts $(29.24 \%)$, the lowest value was in the system with no harvest (25.29\%). The CEL contents were higher in treatments with no harvest and with two cuts with mean values of $34.41 \%$ and $35.29 \%$ respectively and, the lowest cellulose content was observed in the system with one cut, with a mean value of $30.76 \%$. The same behavior was observed with the LIG contents that were higher in the system with no harvest (12.27\%) and with two cuts $(12.31 \%)$, and the lowest value with one cut, $10.79 \%$. Horst et al. (2017), analyzing forage of the same cv. Temprano, at pre-flowering, found values close to those of the present study for fiber components $(27.9 \%$ for HEM, 36.2\% for CEL and 9.7\% for $\mathrm{LIG})$. 
In ruminants, the fiber components, according to Van Soest (1994), are crucial to presume the digestibility potential of forages. The degradation of HEM, according to Campos et al. (2003), is related to the CEL concentration and inversely related to the LIG content, since part of the HEM is more associated with this compound than any other polysaccharide.

In general, the use of fungicide did not influence $(\mathrm{P}>0.05)$ the contents of HEM, CEL and LIG, with the respective mean values: $27.70 \%, 33.49 \%$ and $11.79 \%$. Venancio (2019) evaluated wheat, black oats and white oats in two cuts at the vegetative and full vegetative stages, with and without the application of Pyraclostrobin, in the same experimental field, and detected no significant differences in HEM content, with a mean value of $26.96 \%$ and $27.41 \%$, respectively, for each phenological stage. On the other hand, the levels of CEL and LIG showed differences, and the use of Pyraclostrobin increased the cellulose indices in the two stages, $14.43 \%$ vs $18.61 \%$ at vegetative and $16.93 \%$, vs $20.37 \%$ at full vegetative, and the LIG content decreased with the application of fungicide, from $9.89 \%$ to $6.30 \%$ at vegetative, and from 11.73 to $9.20 \%$ at full vegetative.

Table 2

Contents of hemicellulose, cellulose and lignin of rye cv. Temprano under different harvest systems with or without application of fungicide at pre-flowering

\begin{tabular}{|c|c|c|c|c|c|c|c|c|c|}
\hline \multirow{2}{*}{$\begin{array}{l}\text { Harvest system at } \\
\text { the vegetative stage }\end{array}$} & \multirow{2}{*}{$\begin{array}{c}\text { Fungicide } \\
\text { management }\end{array}$} & \multicolumn{2}{|c|}{ Cuts (DAE) } & \multirow{2}{*}{$\begin{array}{l}\text { Ensilable } \\
\text { forage }\end{array}$} & \multirow{2}{*}{ Mean } & \multicolumn{3}{|c|}{ Probability } & \multirow{2}{*}{$\mathrm{CV} \%$} \\
\hline & & 88 & 135 & & & $(\mathrm{~S})$ & $(\mathrm{F})$ & $(\mathrm{S} * \mathrm{~F})$ & \\
\hline & & \multicolumn{8}{|c|}{ Hemicellulose, \% } \\
\hline \multirow{2}{*}{ No cut } & With & - & - & 23.48 & \multirow{2}{*}{$25.29 \mathrm{~B}$} & \multirow{6}{*}{0.0001} & \multirow{6}{*}{0.0506} & \multirow{6}{*}{0.0618} & \multirow{6}{*}{5,3} \\
\hline & Without & - & - & 27.11 & & & & & \\
\hline \multirow{2}{*}{ One cut } & With & 20.24 & - & 29.20 & \multirow{2}{*}{$28.58 \mathrm{~A}$} & & & & \\
\hline & Without & 19.56 & - & 27.95 & & & & & \\
\hline \multirow{2}{*}{ Two cuts } & With & 27.23 & 20.72 & 29.01 & \multirow{2}{*}{$29.24 \mathrm{~A}$} & & & & \\
\hline & Without & 25.03 & 21.35 & 29.48 & & & & & \\
\hline \multicolumn{2}{|c|}{ Mean with fungicide } & - & - & $27.23 \mathrm{a}$ & - & - & - & - & - \\
\hline \multicolumn{2}{|c|}{ Mean without fungicide } & - & - & $28.18 \mathrm{a}$ & - & - & - & - & - \\
\hline \multicolumn{2}{|c|}{ Overall mean } & 23.02 & 21.04 & 27.70 & - & - & - & - & - \\
\hline & & \multicolumn{8}{|c|}{ Cellulose, $\%$} \\
\hline \multirow{2}{*}{ No cut } & With & - & - & 37.44 & \multirow{2}{*}{$34.41 \mathrm{~A}$} & \multirow{6}{*}{0.0002} & \multirow{6}{*}{0.3110} & \multirow{6}{*}{0.0636} & \multirow{6}{*}{9,3} \\
\hline & Without & - & - & 31.37 & & & & & \\
\hline \multirow{2}{*}{ One cut } & With & 21.86 & - & 30.28 & \multirow{2}{*}{$30.76 \mathrm{~B}$} & & & & \\
\hline & Without & 22.15 & - & 31.24 & & & & & \\
\hline \multirow{2}{*}{ Two cuts } & With & 19.12 & 28.78 & 35.52 & \multirow{2}{*}{$35.29 \mathrm{~A}$} & & & & \\
\hline & Without & 20.07 & 27.03 & 35.07 & & & & & \\
\hline \multicolumn{2}{|c|}{ Mean with fungicide } & & - & - & $34.42 \mathrm{a}$ & - & - & - & - \\
\hline Mean without & ungicide & & - & - & $32.56 \mathrm{a}$ & - & - & - & - \\
\hline Overall $\mathrm{m}$ & & 20.17 & 20.80 & 27.91 & 33.49 & - & - & - & - \\
\hline
\end{tabular}




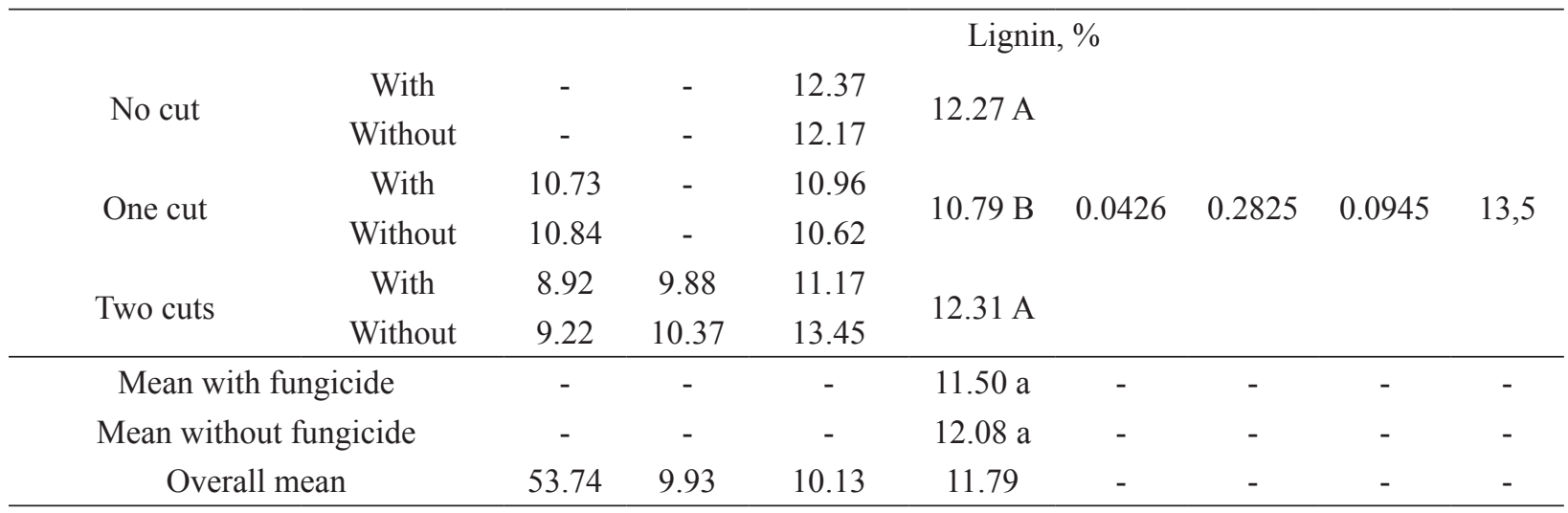

Mean values followed by different capital letters, in the same column, when comparing harvest systems, are significantly different by Tukey's test at $5 \%$ significance.

Mean values followed by different lower case letters, in the same column, when comparing fungicide management, are significantly different by F-test at 5\% significance.

$\mathrm{DAE}=$ Days after emergence; S: Harvest system; F: Fungicide; $\mathrm{S}^{*} \mathrm{~F}$ : Interaction between harvest system and Fungicide.

Figure 1 shows the rate of ruminal disappearance of dry matter of the whole plant in the different treatments tested, the treatment with no harvest with fungicide showed a mean increase of $0.41 \%$ in degradability every hour of exposure to the ruminal microbiota, the treatment without fungicide, $0.47 \%$, the one harvest system with fungicide, $0.44 \%$, and without fungicide, $0.49 \%$, the system with two cuts with fungicide showed a mean value of $0.42 \%$ and the one without fungicide, $0.33 \%$, per hour of exposure.

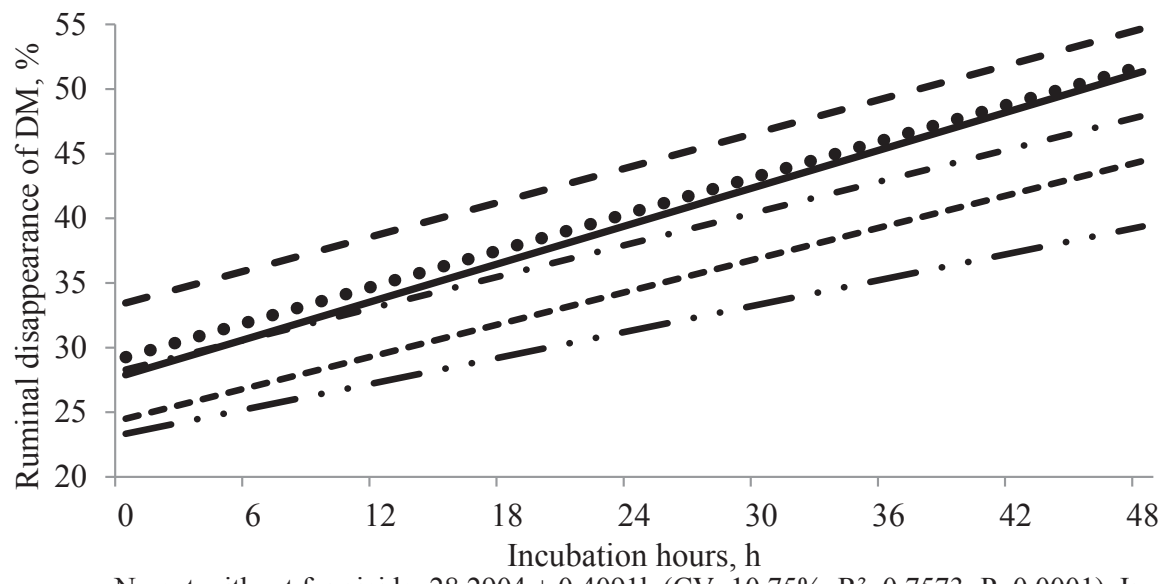

- - No cut without fungicide: $28.2904+0.4091 \mathrm{~h}\left(\mathrm{CV}: 10.75 \% ; \mathrm{R}^{2}: 0.7573 ; \mathrm{P}: 0.0001\right)$, In which $\mathrm{h}$ is incubation hours, from 0 to 48 hours.

$\bullet \bullet-$ No cut without fungicide: $29.2598+0.4693 \mathrm{~h}\left(\mathrm{CV}: 14.58 \% ; \mathrm{R}^{2}: 0.6650 ; \mathrm{P}=0.0001\right)$

- One cut with fungicide: $33.4546+0.4420 \mathrm{~h}\left(\mathrm{CV}: 10.37 \% ; \mathrm{R}^{2}: 0.7447 ; \mathrm{P}=0.0001\right)$

One cut without fungicide: $27.8903+0.4887 \mathrm{~h}\left(\mathrm{CV}: 16.45 \% ; \mathrm{R}^{2}: 0.6399 ; \mathrm{P}=0.0001\right)$

- Two cuts with fungicide: $24.4952+0.4154 \mathrm{~h}\left(\mathrm{CV}: 14.15 \% ; \mathrm{R}^{2}: 0.6959 ; \mathrm{P}=0.0001\right)$

- Two cuts without fungicide: $23.3350+0.3342 \mathrm{~h}\left(\mathrm{CV}: 11.84 \% ; \mathrm{R}^{2}: 0.7170 ; \mathrm{P}=0.0001\right)$

Figure 1. Ruminal disappearance rate of dry matter of rye cv. Temprano under different harvest systems with or without foliar application of fungicide at preflowering. 
Molina et al. (2002) emphasize the importance and viability of the in situ technique or the the nylon bag suspended in the rumen to estimate the ruminal disappearance of dry matter at different times of evaluation of a particular food, mainly due to the simplicity of the method and the savings. Reliable estimates of ruminal disappearance of DM, whether they are forage or protein and energy concentrates, are essential for technicians and farmers when adopting new systems for predicting the nutritional requirements of ruminants. The systems that use fixed digestibility values for each type of food, not taking into account the variation that each food may have even within the same species or under different managements during the crop cycle, may overestimate or underestimate the real use of the food, bringing economic losses to the system (Bumbieris et al., 2011).

When the behavior of the average ruminal disappearance in the different harvest systems is evaluated (Figure 2), it is observed that there was an increasing linear behavior, with a higher degradability value, $0.46 \%$ per hour of exposure, in the one harvest system, followed by the treatment with no cut, $0.44 \%$, and the lowest value, $0.37 \%$, for the system with two cuts.

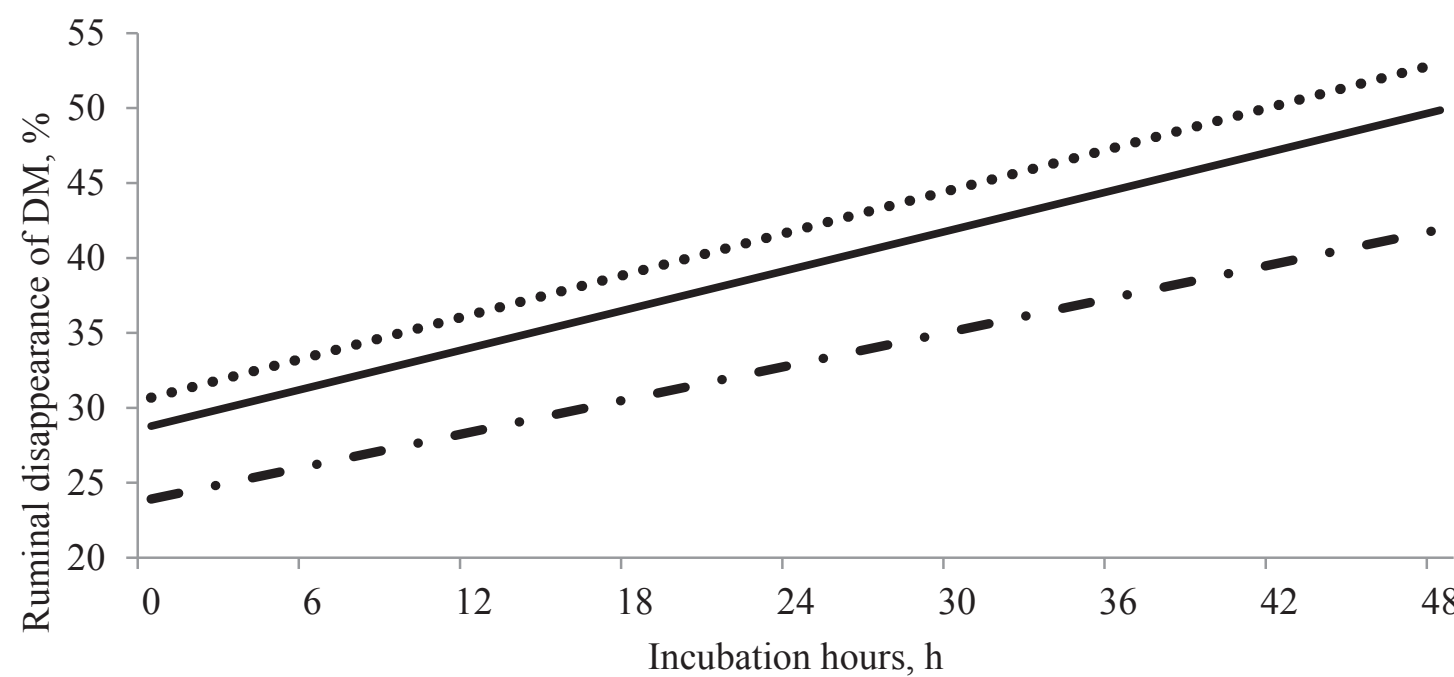

No cut: $28.7751+0.4392 \mathrm{~h}\left(\mathrm{CV}: 13.15 \% ; \mathrm{R}^{2}: 0.6874 ; \mathrm{P}=0.0001\right)$, In which $\mathrm{h}$ is incubation hours, from 0 to 48 hours.

-... One cut: $30.6724+0.4653 \mathrm{~h}\left(\mathrm{CV}: 14.46 \% ; \mathrm{R}^{2}: 0.6433 ; \mathrm{P}=0.0001\right)$

- - Two cuts: $23.9151+0.3748 \mathrm{~h}\left(\mathrm{CV}: 13.93 \% ; \mathrm{R}^{2}: 0.6712 ; \mathrm{P}=0.0001\right)$

Figure 2. Ruminal disappearance rate of dry matter of rye cv. Temprano under different harvest systems.

The greatest ruminal disappearance in the treatment with one cut at the vegetative stage is a direct reflection of its chemical composition in relation to the others, since it presented the lowest LIG values, due to tissue renewal without affecting the final grain production, which makes up the most digestible part of the plant at the rumen level. In the management with two cuts at the vegetative stage, it was observed, as well as that found by Carvalho
\& Pires (2008), greater participation of the fiber portion, combined with lower grain production, which explains the lower disappearance values. Still according to the same authors, the lower degradation found in the treatment with no cut compared to that with one cut is because plants are older, they have greater cell wall thickening and lignification, consequently leading to less use. 
Furthermore, it reaffirms the fact that the fiber content is inversely proportional to the digestibility of the dry matter of the food, in addition to directly impacting the voluntary intake of the animals, since they will need a longer rumination time and consequently show a more pronounced physical filling effect (Van Soest, 1994; Nussio, Campos, \& Lima, 2011).

Figure 3 shows that the use of fungicide had little effect on the rate of ruminal disappearance of dry matter, with a linear increase of $0.42 \%$ per hour of exposure to the rumen environment and $0.43 \%$ without the use of the fungicide.

The use of fungicide did not generate major changes in the disappearance rates; however, the fungicide had the ability to preserve greater amounts of soluble components in the plant, which, as already mentioned, is due to the fungicide physiological effect on the plant.

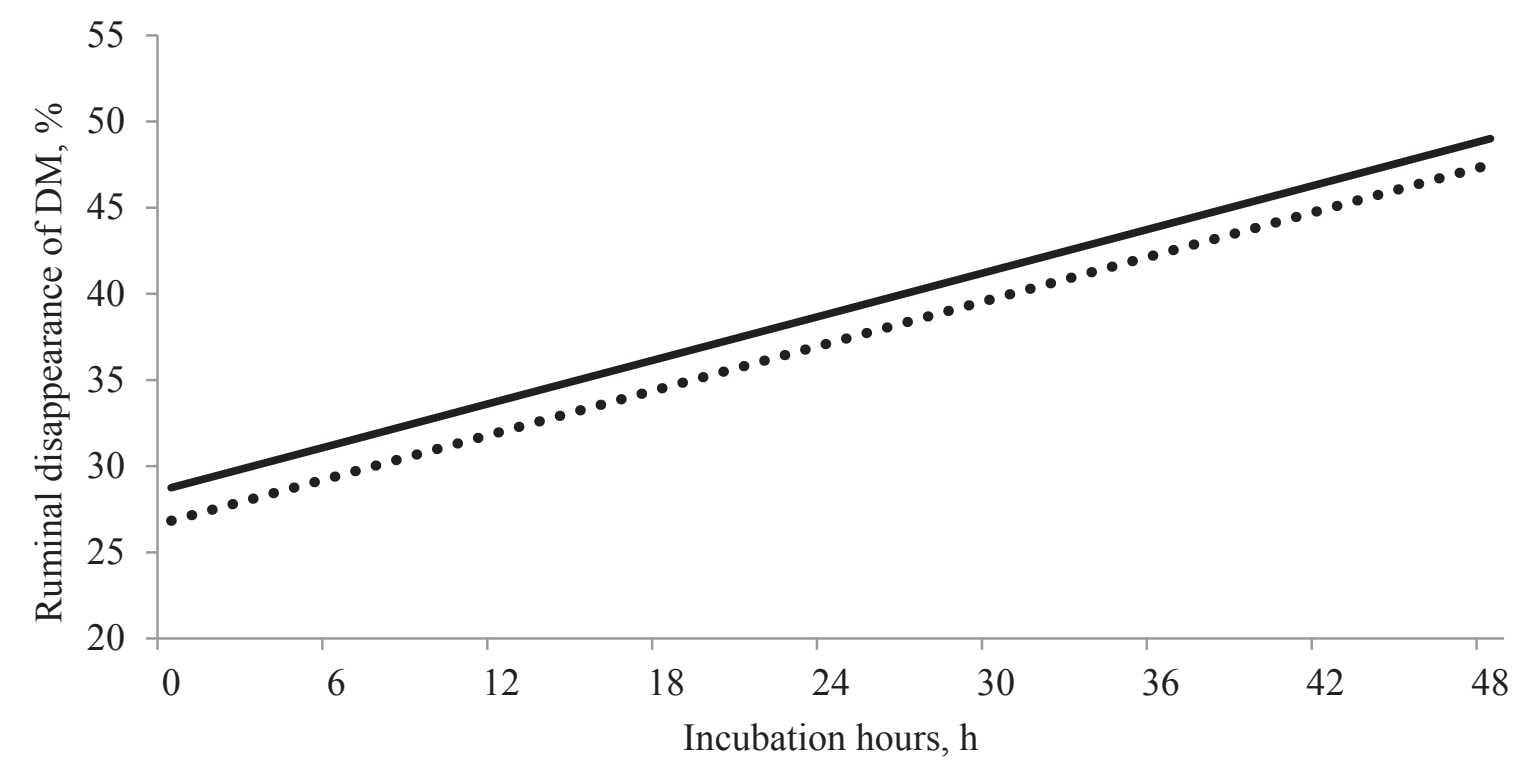

With fungicide: $28.7467+0.4221 \mathrm{~h}\left(\mathrm{CV}: 15.52 \% ; \mathrm{R}^{2}: 0.5959 ; \mathrm{P}: 0.0001\right)$, In which $\mathrm{h}$ is incubation hours, from 0 to 48 hours.

.... Without fungicide: $26.8284+0.4307 \mathrm{~h}\left(\mathrm{CV}: 18.55 \%\right.$; $\mathrm{R}^{2}: 0.5419 ;$ P: 0.0001$)$

Figure 3. Ruminal disappearance rate of dry matter of rye cv. Temprano with or without foliar application of fungicide at pre-flowering.

\section{Conclusion}

With one cut at the vegetative stage and subsequent ensiling at soft dough stage, we obtained the best result in chemical parameters and ruminal disappearance, as the silage presented a better composition of fiber carbohydrates after cutting, which generated better disappearance rates of dry matter at the rumen level.
The application of fungicide promoted improvements in the contents of crude protein and mineral matter of the plant at the time of ensiling.

\section{Referências}

Anke, T. (1995). The antifungal strobilurins and their possible ecological role. Canadian Journal of Botany, 73(S1), 940-945. doi: 10.1139/b95-342 
Association of Official Analytical Chemists (1984). Official methods of analysis. Washington, D.C.: AOAC.

Bumbieris, V. H., Jr., Oliveira, J. R., Jobim, C. C., Barbosa, M. A. A. F., Castro, L. M., \& Barrero, R. P. (2011). Perspectivas para uso de silagem de cereais de inverno no Brasil. Anais do Simpósio de Produção e Utilização de Forragens Conservada, Maringá, PR, Brasil.

Campos, W. E., Saturnino, H. M., Sousa, B. M., Gonçalves, L. C., Borges, I., Rodrigues, J. A. S.,... Ferreira, P. M. (2003). Degradabilidade in situ da silagem de quatro genótipos de sorgo com e sem tanino. II. Fibra detergente neutro, fibra detergente ácido, hemicelulose e celulose. Arquivo Brasileiro de Medicina Veterinária e Zootecnia, 55(4), 450453. doi: 10.1590/S0102-09352003000400010

Carvalho, G. D., \& Pires, A. J. V. (2008). Organização dos tecidos de plantas forrageiras e suas implicações para os ruminantes. Archivos de Zootecnia, 57(1), 13-28. Recuperado de https:/www.uco.es/organiza/ servicios/publica/az/php/az.php?idioma_global=1\& revista $=145 \&$ codigo $=1678$

Caviglione, J. H., Kiihl, L. R. B., Caramori, P. H., Oliveira, D., Galdino, J., Borrozino, E.,... Pugsley, L. (2000). Cartas climáticas do Estado do Paraná. Londrina: IAPAR.

Coan, R., Freitas, D., Reis, R., \& Rodrigues, L. (2001). Composição bromatológica das silagens de forrageiras de inverno submetidas ou não ao emurchecimento e ao uso de aditivos. ARS Veterinária, 17(1), 58-63. Recuperado de http:// www.arsveterinaria.org.br/arquivo/2001/v.17,\%20 n. 1,\% 202001/58-63.pdf

Fagan, E. B., Dourado, D. Neto, Vivian, R., Franco, R. B., Yeda, M. P., Massignam, L. F.,... Martins, K. V. (2010). Efeito da aplicação de piraclostrobina na taxa fotossintética, respiração, atividade da enzima nitrato redutase e produtividade de grãos de soja. Bragantia, 69(4), 771-777. doi: 10.1590/S000687052010000400001

Fontaneli, R. S., Meinerz, G. R., Fontaneli, R. S., Santos, H. P., Biazus, V., Fávero, D., \& Rebechi, I. A. (2016). A contribuição das forrageiras de inverno para a pecuária de leite. In D, Vilela, R. P. Ferreira, E. N. Fernandes, \& F. V. Juntolli (Eds.), Pecuária de leite no Brasil: cenários e avanços tecnológicos (Chap. 5, pp. 239-243). Brasília: EMBRAPA.

Fontaneli, R. S., Santos, H. P. dos, Nascimento, A. D., Jr., Minella, E., \& Caierão, E. (2009). Rendimento e valor nutritivo de cereais de inverno de duplo propósito: forragem verde e silagem ou grãos. Revista Brasileira de Zootecnia, 38(11), 2116-2120. doi: 10.1590 / S1516-35982009001100007

Glaab, J., \& Kaiser, W. M. (1999). Increased nitrate reductase activity in leaf tissue after application of the fungicide Kresoxim-methyl. Planta, 207(3), 442448. doi: $10.1007 / \mathrm{s} 004250050503$

Goering, H. K., \& Van Soest, P. J. (1970). Forage fiber analysis: apparatus reagents, procedures and some applications. Washington, D.C.: Agricultural Handbook.

Grossmann, K., \& Retzlaff, G. (1997). Bioregulatory effects of the fungicidal strobilurin kresoxim $\square$ methyl in wheat (Triticum aestivum). Pesticide Science, 50(1), 11-20. doi: 10.1002/(SICI)10969063 (199705)50:1<11::AID-PS556>3.0.CO;2-8

Horst, E. H., Neumann, M., Santos, J. C. dos, Mareze, J., Mizubuti, I. Y., \& Bumbieris, V. H., Jr. (2017). Fiber composition and degradability of cold season green forage and pre-dried silage harvested at preflowering. Semina: Ciências Agrárias, 38(4), 20412049. doi: 10.5433/1679-0359.2017v38n4p2041

Köehle, H., Grossmann, K., Jabs, T., Gerhard, M., Kaiser, W., Glaab, J.,... Herms, S. (2002). Physiological effects of the strobilurin fungicide F 500 on plants. In H. W. Dehne, U. Gisi, K. H, Kuck, P. E. Russell. \& H. Lyr (Eds.), Modern fungicides and antifungal compounds III. Intercept, Andover, UK. (pp. 61-74).

Leao, G. M., Jobim, C. C., Neumann, M. E., Santos, S. K. dos, Horst, E. H., \& Santos, L. C. dos. (2019). Aspectos produtivos e nutricionais de cereais de inverno em regimes de corte para ensilagem. Archivos de Zootecnia, 68(262), 128-136. Recuperado de https://dialnet.unirioja.es/servlet/articulo?codigo $=6947625$

Lehmen, R. I., Fontaneli, R. S., Fontaneli, R. S., \& Santos, H. P. dos. (2014). Rendimento, valor nutritivo e características fermentativas de silagens de cereais de inverno. Ciência Rural, 44(7), 1180-1185. doi: $10.1590 / 0103-8478 \mathrm{cr} 20130840$.

Maack, R. (2002). Geografia física do Estado do Paraná. Curitiba: Imprensa Oficial.

Molina, L. R., Gonçalves, L. C., Rodriguez, N. M., Rodrigues, J. A. S., Ferreira, J. J., \& Castro, A. G., Neto. (2002). Digestibilidade in situ das frações fibrosas de silagens de seis genótipos de sorgo (Sorghum bicolor (L.) Moench) em diferentes estádios de maturação. Arquivo Brasileiro de Medicina Veterinária e Zootecnia, 54(2), 169-179. doi: 10.1590/S0102-09352002000200008 
National Research Council (2001). Nutrient requeriments of dairy cattle (7nd rev. ed.). Washinton, D.C.: National Academies Press.

Neumann, M., Dochwat, A., Horst, E. H., Venancio, B. J., Santos, J. C., Heker, J. C., Jr.,... Silva, E. P. (2019). Productivity, profitability and nutritional quality of forage and silage of winter cereals. Semina: Ciências Agrárias, 40(3), 1275-1286. doi: 10.5433/1679-0359.2019v40n3p1275

Nocek, J. E. (1988). In situ and other methods to estimate ruminal protein and energy digestibility: a review. Journal of Dairy Science, 71(8), 2051-2069. doi: 10.3168/jds.S0022-0302(88)79781-7

Nussio, L. G., Campos, F. P., \& Lima, M. L. M. (2011) Metabolismo de carboidratos estruturais. In $\mathrm{T}$. T, Berchielli, A. V. Pires, \& S. G. Oliveira (Eds.), Nutrição de ruminantes (pp.193-238). Jaboticabal: Funep.

Pepler, S., Gooding, M. J., Ford, K. E., \& Ellis, R. H. (2005). A temporal limit to the association between flag leaf life extension by fungicides and wheat yields. European Journal of Agronomy, 22(4), 363373. doi: 10.1016/j.eja.2004.06.002

Phillips, W. A., Rao, S. C., Dalrymple, R. L., \& Klepper, E. L. (1996). Annual cool-season grasses. In L. E. Moser, D. R. Buxton \& M. D. Casler (Eds.), Cool $\square$ Season Forage Grasses, (Chap. 26, pp. 781-802). doi: 10.2134/agronmonogr34.c26

Pott, C. A., Müller, M. M. L., \& Bertelli, P. B. (2007). Adubação verde como alternativa agroecológica para recuperação da fertilidade do solo Green manuring as an agroecological alternative for the recovery of soil fertility. Ambiencia, 3(1), 51-63. doi: 10.1111/j.1365-2109.2006.01532.x
Reis, E. M., \& Casa, R. T. (2007). Doenças dos cereais de inverno: diagnose, epidemiologia e controle. Lages: Ed. Graphel.

Silva, D. J., \& Queiroz, A. C. (2009). Análise de alimentos, métodos químicos e biológicos. Viçosa, MG: Universidade Federal de Viçosa.

Sociedade Brasileira de Ciência do Solo, Núcleo Estadual do Paraná (2017). Manual de adubação e calagem para o Estado do Paraná. Curitiba: SBCS/NEPAR.

Statistical Analysis System Institute (1993). SAS Language reference. Cary NC: SAS Institute.

Taiz, L., \& Zeiger, E. (2013). Fisiologia vegetal. Porto Alegre: Artemed.

Van Soest, P. J. (1994) Nutritional ecology of the ruminant. New York, NY: Cornell University Press.

Van Soest, P. V., Robertson, J. B., \& Lewis, B. A. (1991). Methods for dietary fiber, neutral detergent fiber, and nonstarch polysaccharides in relation to animal nutrition. Journal of Dairy Science, 74(10), 35833597. doi: 10.3168/jds.S0022-0302(91)78551-2

Venancio, B. V. (2019) Utililização da piraclostrobina sobre a produção de cereais de inverno. Dissertação de mestrado, Universidade Estadual do CentroOeste, Guarapuava, PR, Brasil. Recuperado de https://www2.unicentro.br/ppgvet/files/2019/04/ Disserta\%C3\%A7\%C3\%A3o-Bruno-Jos\%C3\%A9Venancio.pdf?x26325 
Heker Junior, J. C. et al. 